\title{
Коллоидные квантовые ямы теллурида кадмия: синтез и влияние обмена лигандов на оптические свойства
}

\author{
Л.Д. Козина, А.В.Гаршев, Р.Б.Васильев \\ Московский Государственный Университет им.М.В.Ломоносова, Москва, 119991, Ленинские горы 1 \\ тел:+7 (495) 939-5471, эл. почта: lara.kozina2013@yandex.ru
}

DOI 10.34077/RCSP2019-88

Коллоидные двумерные наночастицы халькогенидов кадмия со свойствами, аналогичными полупроводниковым квантовым ямам, в последнее время вызывают большой интерес благодаря рекордно узким полосам поглощения и люминесценции, делающих их перспективными для создания различных оптоэлектронных устройств [1]. В настоящей работе изучен рост коллоидных двумерных наночастиц теллурида кадмия, а также проанализирована взаимосвязь стабилизирующих лигандов с оптическими свойствами и структурой полученных наночастиц. Лиганды разных типов, такие как длинноцепочечные карбоксилаты, фосфонаты, тиолы, амины имеют разную степень и природу связывания с поверхностью нанокристаллов халькогенидов кадмия, что делает возможным обмен лигандов на поверхности.

Двумерные наночастицы CdTe получены методом коллоидного синтеза в некоординирующем растворителе и инертной атмосфере с использованием олеиновой кислоты в качестве стабилизатора [2]. Подбор температуры роста в диапазоне $150-250^{\circ} \mathrm{C}$ позволил получить наночастицы с толщиной 5 ,

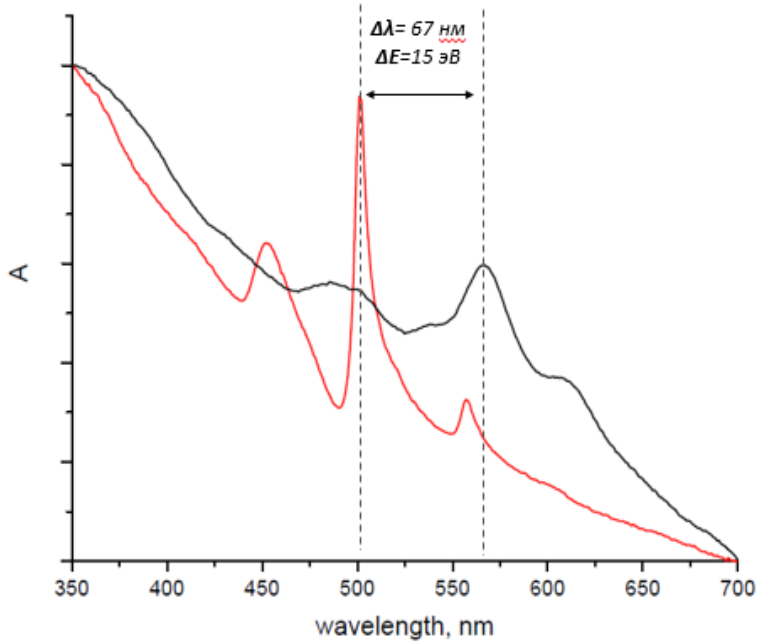

Рис. 1 Спектр поглощения нанолистов CdTe, стабилизированные олеиновой кислотой (а) и октадецилфосфоновой кислотой (б).

6 и 7 монослоев и латеральным размером 100-200 нм. Исследование с использованием методов просвечивающей электронной микроскопии, рентгеновской и электронной дифракции показало совершенную кристаллическую структуру цинковой обманки с тетрагональным искажением. Анализ оптических свойств методами спектроскопии поглощения и люминесценции показал узкие экситонные полосы с шириной порядка 8 нм, спектральное положение которых определялось толщиной наночастицы.

Обмен лигандов на поверхности наночастиц был проведен методом межфазного переноса. Изучены лиганды ряда тиолов и фосфоновых кислот. Было показано, что замена олеиновой кислоты на тиолы и додецилфосфоновую кислоту приводит к спектральному сдвигу экситонных полос в красную область на величину до 70 нм (рис.1). Структура полос при этом сохранялась. Анализ кристаллической структуры дифракционными методами показал сохранение структуры цинковой обманки, однако с перераспределением ширин и интенсивностей рефлексов, указывающее на сжимающие механические напряжения. В то же время в малоугловой области наблюдались выраженные рефлексы, отвечающие образованию многостенных структур с расстоянием между слоями, сопоставимым с удвоенным размером молекулы лиганда. Методом просвечивающей электронной микроскопии показано формирование многостенных свернутых наноструктур, причем диаметр сворачивания определялся толщиной наночастицы.

Работа выполнена при поддержке грантов РФФИ 16-29-11694 и 19-03-00481.

\section{Лumepamypa}

[1] M. Nasilowski et al. // Chem. Rev. 2016, 116, 10934.

[2] R.B.Vasiliev et.al. // Chem. Mater. 2018, 30 (5), pp 1710-1717. 